\title{
毒物に依る魚介類の死亡一I。 化學薬品飞よる稚鯉の死亡
}

吂 原 友占・阿部博 (東京水痤大学)

The Toxicity of Chemicals on Fish - I .

Death of the Young Carp, Cyprinus carpio Linne, by Ehemicals

Tomokichi Yoshinara and Hiroshi ABE

In order to make contribution, to our knowledge of various effect of chemicals on fish, young carps wete kept in the water which contains various chemical substance with various concentrations, and their responses in accordance with time were obsrved.

The results were analysed by the probit analysis using the probability paper. In Fig, 3, the relationship between the concentration of chemicals and the mean survival time is shown.

\section{1.ま ‡ が}

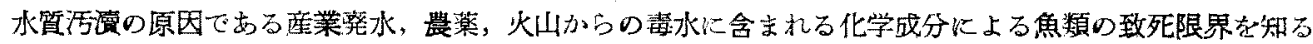

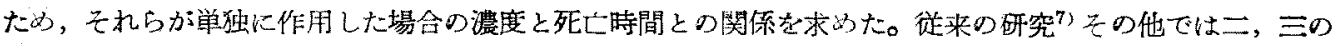

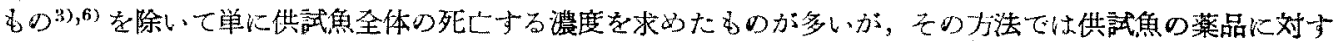
る個体差を考思してない。，本報では毒物濃度が一定であれば，各個体り致死時间或しはその対数は近似的に

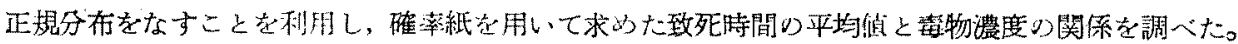

ここに得られた結果うら，弩物の濃度と作用時間がきまれば，全体の问％が死亡するかを推定出来る。件

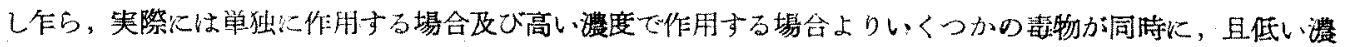

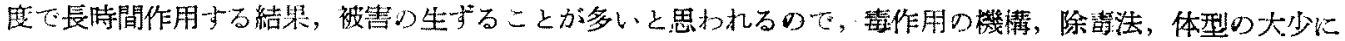
よ召抵抗力の差についての䎲究上共にこの方面の研究を進める必要がある。本報では主として無機化学蕒品

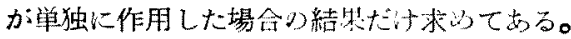

\section{2. 半数 死亡 時}

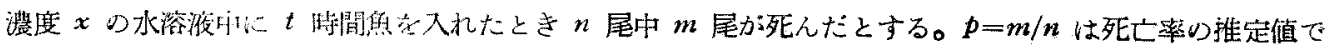
$x$ 之 $t$ D函数でかる。

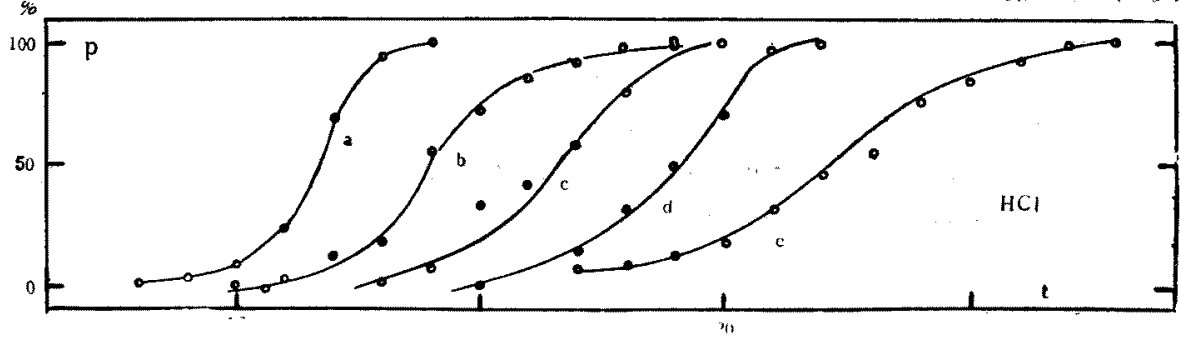

Fig. 1. Relationship between the concentration of $\mathrm{HCl}$ ( $x$ mol.) and percentage kill $(p \%)$ of carp, showing the normal sigmoid curve.

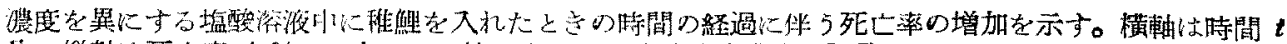
分，緃軸は死亡率 $p \%, a, b, c \cdots$ 第 2 表に示与塩酸溶液濃度の記号。 


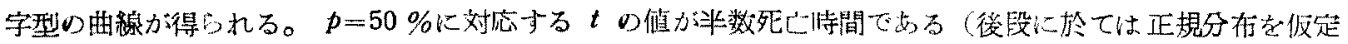
するから，乙机は平均死亡時間に一致するう。

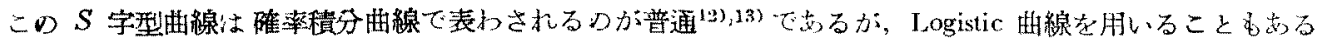
10),11)。但し通常 Probit Analysisでは $t$ を一定にしてx 夌变た場合について論じられる。又横軸には $t$ 又は $x$ の代りにその対数を目盛ることが多いか。本報では濃度 $x$ て㭙間 $t$ 宋で死亡した個体の割合

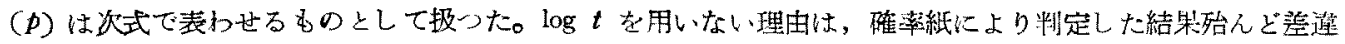
が翏められなからたからである。

$$
p=\frac{1}{\sqrt{2} 2 \pi \sigma} \int_{-\infty}^{t} \exp \left[-\frac{(t-r)^{2}}{22^{2}}\right] d t
$$

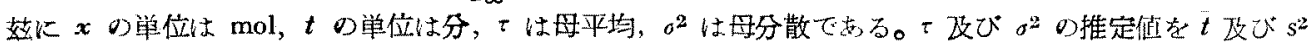
と表放す。

\section{3. 実䮞}

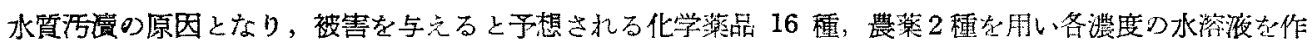

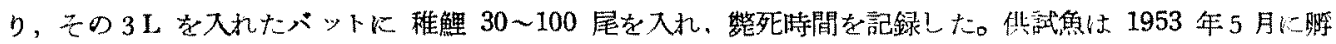

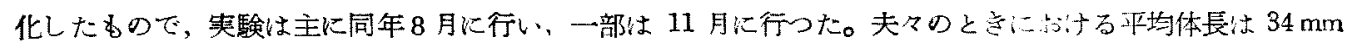
及び $45 \mathrm{~mm}$ で，予如出来る丈同一体長のものを選別して用いた。使用藻品は第 1表こ示す如くで，鸤酸り 場合のみについてて死亡時間を第 2 表に示した。

Table 1. Names of chemicals used and their concentration.

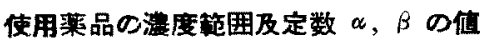

\begin{tabular}{|c|c|c|c|c|c|c|}
\hline 記号 & 薬 & $\begin{array}{l}\text { 品 } \\
\text { emicals }\end{array}$ & $\alpha$ & $\beta$ & $\begin{array}{l}\text { 濃 } \\
\text { Conc }\end{array}$ & $\begin{array}{l}\text { 度 (mol) } \\
\text { entration }\end{array}$ \\
\hline $\begin{array}{l}\mathrm{A} \\
\mathrm{B} \\
\mathrm{C} \\
\mathrm{D} \\
\mathrm{E}\end{array}$ & $\begin{array}{l}\mathrm{HCl} \\
\mathrm{BaCl}_{2} \\
\mathrm{NH}_{4} \mathrm{Cl} \\
\mathrm{CaCl}_{2} \\
\mathrm{H}_{2} \mathrm{SO}_{4}\end{array}$ & 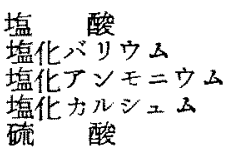 & $\begin{array}{l}-0.26 \\
-1.24 \\
-2.19 \\
-2.09 \\
-0.36\end{array}$ & $\begin{array}{r}0.82 \\
-0.02 \\
0.07 \\
0.31 \\
0.28\end{array}$ & $\begin{array}{l}0.075 \\
0.06 \\
0.37 \\
0.65 \\
0.0041\end{array}$ & $\begin{array}{l}\sim 0.0075 \\
\sim 0.024 \\
\sim 0.12 \\
\sim 0.13 \\
\sim 0.0006\end{array}$ \\
\hline $\begin{array}{l}\mathbf{F} \\
\mathrm{G} \\
\mathbf{H} \\
\mathbf{I} \\
\mathbf{J}\end{array}$ & $\begin{array}{l}\left(\mathrm{NH}_{4}\right)_{2} \mathrm{SO}_{4} \\
\mathrm{CuSO}_{4} \\
\mathrm{FeSO}_{4} \\
\mathrm{CrK}\left(\mathrm{SO}_{4}\right)_{2} \\
\mathrm{KOH}\end{array}$ & 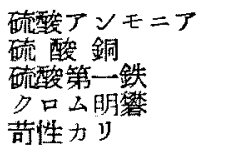 & $\begin{array}{l}-0.54 \\
-0.02 \\
-0.74 \\
-1.28 \\
-1.04\end{array}$ & $\begin{array}{r}1.13 \\
1.45 \\
0.78 \\
-0.31 \\
-1.16\end{array}$ & $\begin{array}{l}0.30 \\
0.12 \\
0.12 \\
0.13 \\
0.008\end{array}$ & $\begin{array}{l}\sim 0.008 \\
\sim 0.01 \\
\sim 0.02 \\
\sim 0.007 \\
\sim 0.004\end{array}$ \\
\hline $\begin{array}{l}\mathrm{K} \\
\mathrm{L} \\
\mathrm{M} \\
\mathrm{N} \\
\mathrm{O}\end{array}$ & $\begin{array}{l}\mathrm{KCN} \\
\mathrm{NaOH} \mathrm{Na}_{2} \mathrm{CO}_{3} \\
\mathrm{C}_{2} \mathrm{H}_{4} \mathrm{O}_{2} \\
\mathrm{H}_{3} \mathrm{PO}_{4}\end{array}$ & 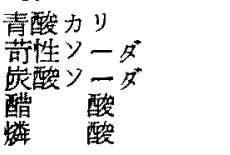 & $\begin{array}{l}-0.55 \\
-1.83 \\
-0.46 \\
-1.03 \\
-0.47\end{array}$ & $\begin{array}{r}-0.75 \\
-2.96 \\
0.39 \\
0.23 \\
-0.18\end{array}$ & $\begin{array}{l}0.001 \\
0.0075 \\
0.028 \\
0.20 \\
0.004\end{array}$ & $\begin{array}{l}\sim 0.00006 \\
\sim 0.0045 \\
\sim 0.007 \\
\sim 0.020 \\
\sim 0.002\end{array}$ \\
\hline $\begin{array}{l}\mathrm{P} \\
\mathrm{Q} \\
\mathrm{R}\end{array}$ & 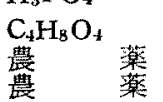 & 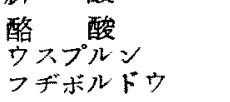 & $\begin{array}{r}-1.34 \\
-0.27 \\
-0.55\end{array}$ & $\begin{array}{r}-1.63 \\
1.09 \\
0.70\end{array}$ & $\begin{array}{r}0.013 \\
\times 100 \\
\times 100\end{array}$ & $\begin{array}{l}\sim 0.002 \\
\sim 7100 \text { (倍 } \\
\sim 900 \quad \text { " }\end{array}$ \\
\hline
\end{tabular}

Table 2. Toxicity of $\mathrm{HCl}$ to carp, percentage kill at various concentration.

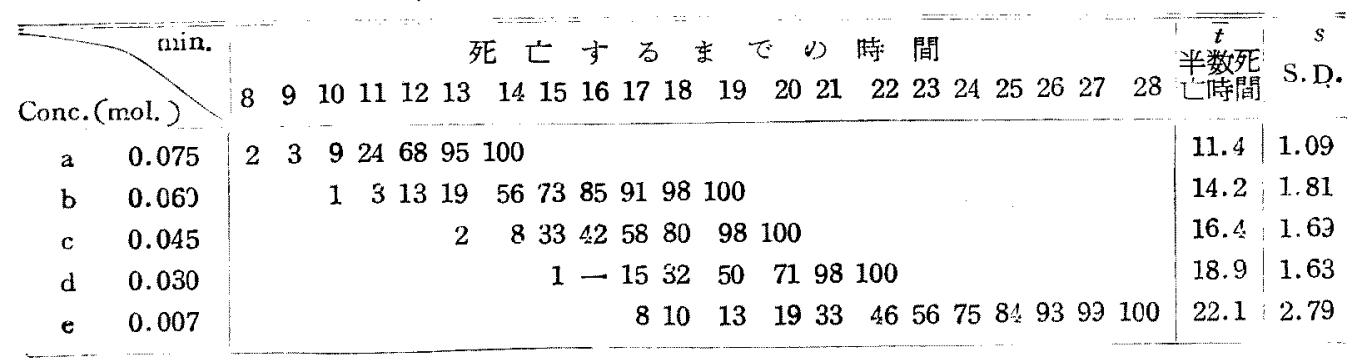

塩酸を湖いて行つた笑験結果, 気温 $29.1^{\circ} \mathrm{C}$, 水温 $24.8 \sim 25.0^{\circ} \mathrm{C}$, 平均体長 $35 \mathrm{~mm}$, 標淮偏差は各瑇

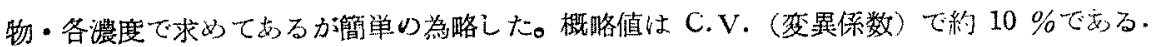




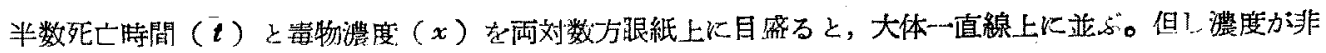
常に低い場合には $100 \%$ 死亡しない為に，この直線から外机る。例えば塩酸の場合には第 2 图に示す如くで

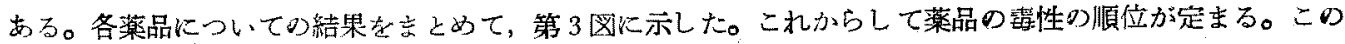
㵵合記号 $G$ で示した硫酸晍は，実験䈥囲内の濃度では同程度の毒性を示すことに注意を姴する。

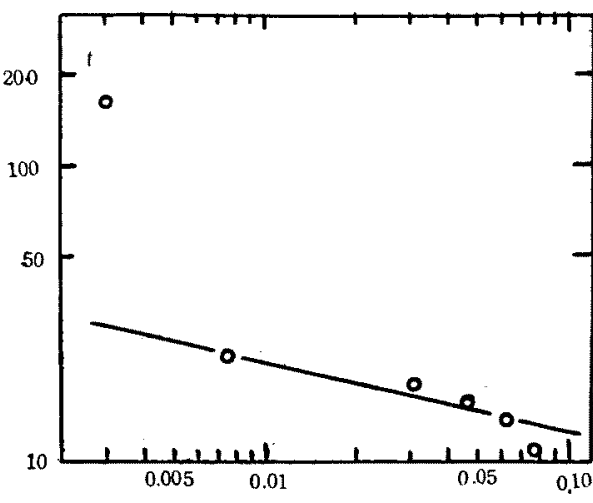

Fig. 2. Relationship between the concentra. tion of $\mathrm{HCl}(x \mathrm{~mol}$.$) and the mean survival$ time ( $t$ min.)

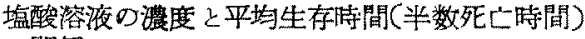
D閔保

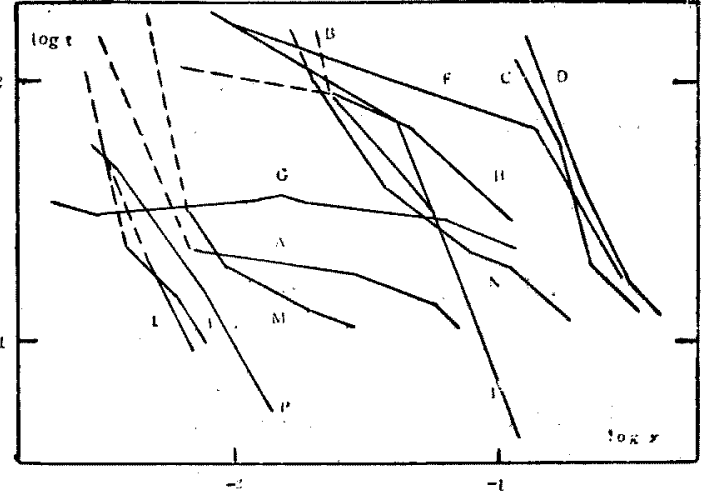

Fig. 3. Relationship between the concentration of chemicals and the mean survival time on various chemical subtance. A, B, C, $\cdots$. are names of chemicals shown in Table 1.

各檑請物溶液の浂度之平均生存㭙間》関係

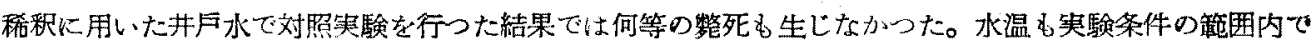
は影響が諗められなからた。

\section{5. 論}

湦度 $\boldsymbol{x}$ のときの probit 回帰直線(4),5) の方程式は，死亡率 (

$$
\boldsymbol{y}=(\boldsymbol{t}-\bar{t}) / s+5
$$

で与えられる。ここに $\bar{t}$ 上 $s^{2}$ は母平均欧び母分散の推定值であつて，塩酸の場合には第 2 表の如くなる。

$x z \bar{t}$ の阔係は近似的に上述の如く

$$
\log \bar{t}=\alpha \log x+\beta
$$

と表わさ机る。この $\alpha$ と $\beta$ の值は第1表に示してむるが， $\alpha<0$ であるから $\alpha=-A, 10^{\beta}=B$ とおく 之,

$$
\bar{t}=B x^{-A}
$$

なる Ostwald の法則2)が求亲る。

$\log \bar{t}$ 之 $\log s$ 間には近似的に直舶関你が成立する。これら両関保は,ボウフラについても認められてい

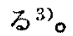

農薬については2 種だけについて試験したが, BHC(i),9), Rotenone 6),8)，ホリドール 1),9) についてむ研究 されている。その後，多くの研究者より種々な農業についての研究が発表されているが，著者も办研究中で 求るから，その結果は次報で述べる。

\section{6. 謝辞}

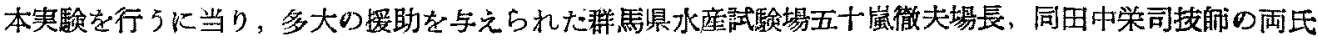
に深謝する。 
文解

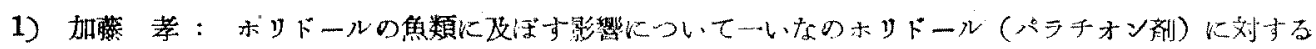
㧹抗珄 徳島水敦だより，No. 5, 1953，9-12.

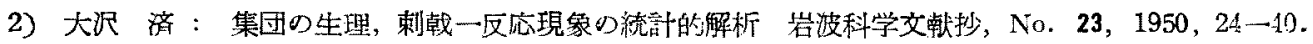

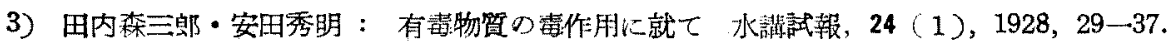

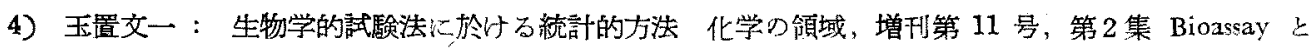
推䛠学 1953.,9-44.

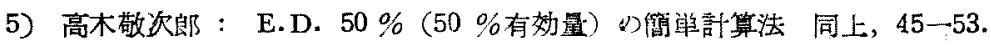

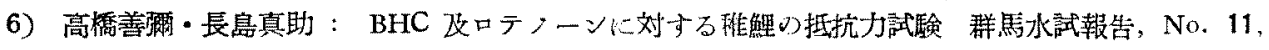
(昭和 $25-27$ 年度) $1954,32-53$.

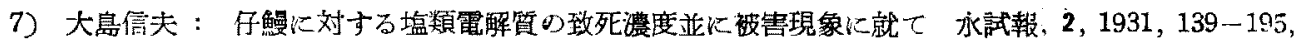

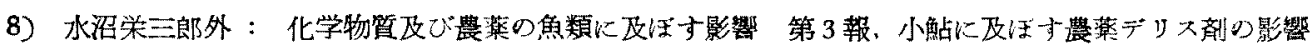
滋賀水試研·報 4, 1953 .

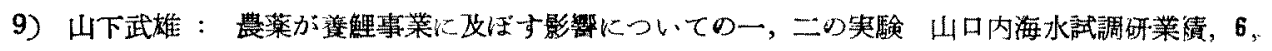
$1954,5-60$.

10) Berzson, J. "Application of the logistic function to bio-assay", J. Amer. Stat. Asoc. 39, 1944, 357-365.

11) Berkson, J. "A statistical precise and relatively simple method of estimating the bio-assay with response, based on the logistic function", J. Amer. Stat. Asoc. 48, 1953, 565 599 .

12) BuIss, C.I. "The statistics of bio-a say with special reference to the vitamins", Reprinted from Vitamin Methods Vol. 2, 1952, 448-628.

13) Finney, D.J. "Probit analysis", 2 nd ed. 1952. 